Dep. of Environmental and Health Studies, The Custodian of the Two Holy Mosques Institute for Hajj Research, Umm Al-Qura University, KSA.

\title{
EFFECT OF HOT WATER ON AEROBIC PLATE COUNT AND QUALITY OF SHEEP SACRIFICE CARCASSES
}

(With 3 Tables)

By

\author{
B.H.H. MASHAT
}

(Received at 2/9/2009)

\section{SUMMARY}

Many thousands (more than 700,000) of sacrificial animals are slaughtered every year through the project of Kingdom of Saudi Arabia for the utilization of Hadi and Adahia (Sacrificial) meat during Hajj season. During the slaughter and preparation of sacrificial animals, the surfaces of dressed carcasses becomes contaminated with large numbers of microorganisms as a result of very fast skinning and evisceration faults. This is caused by the fact that butchers entrusted with slaughtering and skinning are paid per head to encourage them produce the largest numbers possible within the timeframe allowed by Islamic Shari'ah. (84 hours). The main objective of this study was conducted to investigate the microbiological impact of washing sheep sacrifice carcasses with hot water at different temperatures $\left(60\right.$ and $\left.70^{\circ} \mathrm{C}\right)$. A whole carcass rinse was performed on each carcass before (control) and after washing (final). The result showed that the two temperature treatments significantly reduced aerobic plate counts (APC) on the animal sacrifice carcasses in comparison with untreated controls. No significant differences $(\mathrm{P}>0.05)$ were found in the subjective evaluation of lean appearance, colour appearance, odour, and overall acceptability between treated and untreated sheep sacrifice carcasses after $48 \mathrm{~h}$ of chilling and chilled storage.

Key words: Decontamination, hot water, carcass microbiology, sacrificial sheep.

\section{INTRODUCTION}

Hajj (Pilgrimage) involves certain religious rites that should be performed at particular times and at certain places. Among these rites is the sacrifice of whatever cattle or sheep the pilgrim can easily afford. 
Pilgrims of diverse races, customs and social levels are anxious to follow the Sunnah (the way and the manners of the Prophet - All Prayers and Blessings of Allah be upon him) by slaughtering the sacrificial animals by themselves. Some of these animals are left at their place of slaughter without being utilized with the result that the discarded meat finally becomes a menace to public health and the environment.

In the past when the number of pilgrims was small, comparatively few animals were slaughtered and their meat was therefore fully utilized. With the beginning of the age of modern transportation, the number of Moslems undertaking the hajj journey increased substantially. This implied that consequent increasing numbers of slaughtered animals would be fully utilized to meet the pilgrims' needs for meat during their long stay in Makkah.

The pilgrims' attitude towards the sacrifice of animals is of great importance. Unfortunately, however, many pilgrims are not attentive to the requirements that should be met by sacrificial animals. Anxious only to shed the blood of sacrificial animals, some pilgrims buy animals that are unfit to be offered as sacrifices. This might be attributed to some pilgrims' ignorance of the Shari'ah rules (Islamic religious law) governing the buying and slaughtering of sacrificial animals. Moreover, the majority of pilgrims leave the slaughtered animals at their place of slaughter, not making use of their meat because of overcrowding and the extremely hot weather. In order to realize this noble objective, the government of the Kingdom of Saudi Arabia established the "Saudi Project for Utilization of Sacrificial Animals" since 1983 to help realize the Shari'ah objectives of Hajj and to enable Muslim pilgrims to benefit form their Hajj and its rituals.

During the slaughter of sacrificial animals the carcasses surfaces become contaminated with large numbers of microorganisms, this because of cuts and punctures resulting from very fast skinning operations. This is caused by the fact that butchers entrusted with slaughtering and skinning are paid per head to encourage them produce the largest numbers possible within the timeframe allowed by Islamic Shari'ah. This prescribed timeframe extends from end of Eid prayers to the sunset of the third day following the day of Eid, which makes a total of 84 hours. During these hours work is performed around the clock (24 hours) in shifts. This speed in which butchers try to finish as many numbers of animals as possible resulted, as said earlier, in damage to the skin of slaughtered animals, which made merchants shun the purchase of these damaged skins. 
However, microbial contamination occurs during many of the series of slaughtering processes that are required to convert a live animal to meat fit for human consumption. The muscle tissue of a healthy animal is essentially sterile (Gill, 1979; Gill, 1980; James and Evans, 2006; Downey et al., 2007), and most of the initial contamination of a lamb carcass takes place during fleece removal and evisceration. Reducing surface contamination would improve food safety and extend shelf life. James and James (1997) have extensively reviewed the range of surface decontamination methods that may have application to red meat.

In addition, hot water has been shown to be effective in reducing the number of microorganisms on meat surfaces (Karmas, 1975; Morgan et al., 1996 a and b; Corrya et al., 2007). Smith and Graham (1978) and Corrya et al., (1995) also showed that hot water immersion of mutton carcasses could reduce Escherichia coli counts by $3 \log _{10}$ units.

However, decontamination by hot water may also adversely affect qualities that control carcass acceptability, i.e., 'bloom', colour and odour (Al-sheddy et al., 1995; James et al., 2000; Kelly et al., 2007; Kelly et al., 2008). Bloom is a very subjective judgment of the overall attractiveness of the carcass. High pressure cold water sprays may adversely affect bloom (James et al., 2000). An efficient decontamination system should reduce bacterial numbers without any detrimental changes to the appearance of the carcass.

It is worth to mention that the present study was undertaken to determine the effectiveness of washing animal sacrifice carcasses with hot water at high temperature $\left(60{ }^{\circ} \mathrm{C}\right.$ or $\left.70{ }^{\circ} \mathrm{C}\right)$. All treatments were applied for $15 \mathrm{sec}$. Preliminary investigations had indicated that exposure time more than this would produce unacceptable surface changes on exposed muscle tissue. The effect of washing with hot water on microbial numbers, appearance, odour, and overall acceptability were all assessed.

Overall, the aim of this work was to produce animal sacrifice carcasses that would have the acceptable quality traits which consumers expect of fresh lamb together with significantly decreased microbiological counts.

\section{MATERIALS and METHODS}

One hundred sheep sacrifice (carcass weights of 17-22 kg) were randomly selected for washing with hot water. Immediately after animal sacrifice slaughter the carcasses were eviscerated and dressed. Following 
dressing the carcasses were manually washed with cold $\left(15 \pm 2^{\circ} \mathrm{C}\right)$ potable water, for approximately $15 \mathrm{sec}$. Water temperatures were maintained at either $60{ }^{\circ} \mathrm{C}$ or $70{ }^{\circ} \mathrm{C}$ using electrical instant water heater (BT-1 LUX), for approximately $15 \mathrm{sec}$. All the carcasses were health marked, classified for conformation and scored for the development of fat cover relative to the dimensions of the carcass.

The effectiveness of the washing procedure was determined by sampling adjacent $10 \mathrm{~cm}^{2}$ areas outside of both neck and abdomen. Samples were taken before and after washing. The bacteria from the 10 $\mathrm{cm}^{2}$ area described by a sterile paperboard template were removed by swabbing the area for about $15 \mathrm{sec}$. using a cotton swab moistened with $0.1 \%$ peptone water solution. Serial dilutions were done from the original dilution in $0.1 \%$ peptone water and were plated in triplicate on Nutrient Agar (Oxoid CM3) in Petri dishes and were incubated for $48 \mathrm{~h}$ at $35^{\circ} \mathrm{C}$.

Sampling was undertaken using the dry swabbing method described by María-Luisa et al. (1997) and Gill and Jones (2000). A 10 $\mathrm{cm}^{2}$ area delineated by a sterile metal template was used. A swab (Medical Wire, MW 104) was moistened in diluent (90.1\% peptone, $0.85 \% \mathrm{NaCl}$ ), and the sampling site swabbed in a standard manner using 10 horizontal and 10 vertical passes over a previously defined area inside a $10 \mathrm{~cm}^{2}$ template. The swab was broken off into diluent $(90.1 \%$ peptone, $0.85 \% \mathrm{NaCl}$ ), whereas the used diluent was $10 \mathrm{ml}$ peptide saline contained in a universal bottle (McCartney) with 4-5 glass beads. These were stored in a commercial chill room operating at $2^{\circ} \mathrm{C}$ for a maximum of $2 \mathrm{~h}$ before microbiological examination. To reduce the error introduced by manual sampling techniques, all swab samples were taken by the same individual.

Appropriate serial dilutions were done and plated on Nutrient Agar (Oxoid CM3) to determine the aerobic plate count (APC). The plates were incubated for $48 \mathrm{~h}$ at $30^{\circ} \mathrm{C}$. Nutrient Agar was used in preference to plate count agar (PCA) since it is more suitable. Counts were calculated as colony forming units per centimeter square (CFU $\mathrm{cm}^{-2}$ ) using the surface counting method.

Carcass quality were assessed for lean appearance, colour, odour and overall acceptability using a 6-point hedonic scale after $24 \mathrm{~h}$. (Table 1). 
Table 1: Six-point scale used to access carcass quality after $48 \mathrm{~h}$.

\begin{tabular}{|l|l|l|}
\hline \multirow{2}{*}{\multicolumn{1}{|c|}{ Quality }} & \multicolumn{2}{c|}{ Six-point scale } \\
\cline { 2 - 3 } & \multicolumn{1}{c|}{1} & \multicolumn{1}{c|}{2} \\
\hline Lean appearance & Very dehydrated & Very fresh \\
\hline Colour appearance & Very dark & Milk white \\
\hline Odour assessment & Very stale & Very fresh \\
\hline Overall acceptability & Dislike intensely & Like intensely \\
\hline
\end{tabular}

\section{Statistical analysis}

All microbial counts were transformed to $\log _{10}$ values for statistical analysis. The data $\left({\operatorname{as~} \log _{10} \mathrm{CFU} \mathrm{cm}}^{-2}\right)$ were analyzed using the software package SPSS $\odot$ for Windows (SPSS@ Inc. Chicago, IL). The paired $t$-test was used to investigate the microbiological impact of washing animal sacrifice carcasses with hot water. Differences in microbiological counts obtained at different sites and treatments were compared by analysis of variance. When a significant $(\mathrm{P}<0.05)$ difference was observed, Duncan's multiple range test was used to detect the differences between groups.

\section{RESULTS}

\section{Total viable counts at 55 min post-mortem}

The mean APC at the two sampling sites for the control and decontamination treatments are shown in Table 2. Mean counts from the

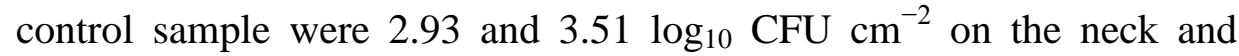
abdomen, respectively.

In all cases, the mean APC on the abdomen was higher than that from the neck sample. In addition, the largest reduction of $3.75 \log _{10}$

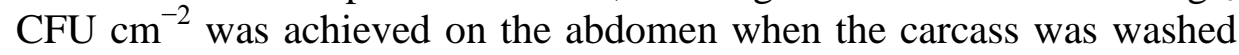
with the hot water at $70{ }^{\circ} \mathrm{C}$. The lowest reduction of $2.53 \log 10 \mathrm{CFU}$ $\mathrm{cm}^{-2}$ was achieved on the neck when the carcass was washed with the hot water at $70{ }^{\circ} \mathrm{C}$. While, however statistical analysis of the results showed that the mean counts for each sampling site were significantly lower (P 0.05) for the treated carcasses than the controls. Overall, the combination of hot water at $70{ }^{\circ} \mathrm{C}$ resulted in a statistically lower (P 0.05) count than the hot water at $60{ }^{\circ} \mathrm{C}$ treatments. 
Table 2: Mean APC at two sampling sites on sheep sacrifice carcasses subjected to two different decontamination treatments.

\begin{tabular}{|l|c|c|c|}
\hline \multirow{2}{*}{ Treatment } & \multicolumn{2}{|c|}{ APC $\log 10(\mathrm{CFU}$ ml-2) } & \multirow{2}{*}{ Overall } \\
\cline { 2 - 3 } & Neck & Abdomen & \\
\hline Washed with potable water & 7.17 & 11.19 & 9.18 \\
\hline Washed with hot water at $60^{\circ} \mathrm{C}$ & 6.4 & 9.67 & 8.035 \\
\hline Washed with hot water at $70^{\circ} \mathrm{C}$ & 5.28 & 7.87 & 6.575 \\
\hline
\end{tabular}

\section{Chilling rate}

The temperature in the deep leg of the animal sacrifices was reduced to $7^{\circ} \mathrm{C}$ by approximately $5.2 \mathrm{~h}$. post-mortem.

\section{Carcass quality}

There were no significant differences $(\mathrm{P}>0.05)$ in the objective evaluation of lean appearance, colour, odour, and overall acceptability between treated and control animal sacrifice carcasses after $48 \mathrm{~h}$. chilling and storage (Table 3).

\subsection{Control carcasses}

The control carcasses appeared 'normal' with the visual quality traits of young animal sacrifice after chilling. The attractive bright, cherry red colour associated with freshness was visible in all carcasses.

\subsection{Hot water at $70{ }^{\circ} \mathrm{C}$-treated carcasses}

Hot water at $70{ }^{\circ} \mathrm{C}$-treated carcasses were considered acceptable. Greying or bleaching of the carcass surface was noticeable immediately after steam treatment. However, acceptable colour returned after chilling and storage for $48 \mathrm{~h}$.

\subsection{Hot water at $60{ }^{\circ} \mathrm{C}$-treated carcasses}

Hot water at $60{ }^{\circ} \mathrm{C}$-treated carcasses were considered acceptable. Immediately after treatment, while the carcasses were draining, they had a slightly cooked appearance on the thin edges and exposed cut muscle surfaces. This was especially noticeable on the exterior panniculua 'bark' muscle surface and the interior (thorax, kidneys and abdomen) of the animal sacrifice carcasses. In general, acceptable colour returned after chilling and storage for $48 \mathrm{~h}$.

Table 3: Mean overall appearance scores for treated and untreated sheep sacrifice carcasses at $48 \mathrm{~h}$ post-mortem.

\begin{tabular}{|l|c|c|c|}
\hline Quality & Potable water & Hot water at $60^{\circ} \mathrm{C}$ & Hot water at $70^{\circ} \mathrm{C}$ \\
\hline Lean & 4.33 & 4.13 & 4.75 \\
\hline Colour & 3.33 & 3.6 & 4.45 \\
\hline Odour & 4.43 & 4.53 & 4.73 \\
\hline Acceptability & 4.6 & 4.73 & 4.45 \\
\hline
\end{tabular}




\section{DISCUSSION}

There is general agreement that the main source of bacterial contamination on a meat carcass is from the animals sacrifice themselves. At the point of slaughter the musculature of the animal is effectively sterile and initial contamination occurs on the exposed surface. The main sources of contamination are the skin, hooves, etc., of the animal; faeces voided by the animals sacrifice; bacteria derived from the opened gut; and soil, dust, etc., carried to the killing-floor. Two main routes of contamination have been identified: (1) Deposition of bacteria scattered in the air and splashing with contaminated faeces, etc. and (2) Contact with dirty instruments, hands, clothes, etc.

However, washing was reported to be one of the important steps in improving the hygienic quality of carcasses. Ellerbroek et al. (1993) and Gill et al. (1996) reported that washing of lamb carcasses reduced the microbial load considerably on carcasses. Gill and Baker (1998) showed that washing reduced the log numbers of aerobic bacteria, coliform and Escherichia coli by approximately 0.5. In our study, washing neck and abdomen of animal sacrifice carcasses at $60{ }^{\circ} \mathrm{C}$ brought a reduction of 1.78 and $3.43 \log _{10} \mathrm{CFU} / \mathrm{cm}^{-2}$ in viable microbial counts, respectively. While whoever, washing neck and abdomen of animal sacrifice carcasses at $70{ }^{\circ} \mathrm{C}$ brought a reduction of 0.92 and 2.26 $\log _{10} \mathrm{CFU} / \mathrm{cm}^{\mathrm{zZ}}$ in viable microbial counts, respectively. However, this decrease in count after washing was statistically significant.

In the present investigation the work was carried out on neck and abdomen of animal sacrifice carcasses slaughtered and processed in near commercial conditions. The most comparable published work is that by Bailey (1971); James et al. (2000) and Kelly et al. (1981), Kelly et al. (1982) and Siragusa, (1995) relating to spray washing, Smith and Graham (1978) on immersion, and Dorsa, et al. (1996) on steam. In Bailey's studies reductions of between 0.6 and $0.8 \log 10$ per carcass were achieved (Bailey, 1971, 1972; Bailey and Reborts; 1976). Kelly et al. (1981) found that water temperatures of $80^{\circ} \mathrm{C}$ were required to obtain reductions of $1 \log _{10} \mathrm{CFU} \mathrm{\textrm {cm } ^ { - 2 }}$, from initial counts of between 3.2 to $4.2 \log _{10} \mathrm{CFU} \mathrm{cm}{ }^{-2}$. Trials by Smith and Graham (1978) on naturally contaminated carcasses reduced counts from around 3.9 to 2.5 $\log _{10} \mathrm{CFU} \mathrm{cm} \mathrm{cm}^{-2}$ by immersing in water at $80^{\circ} \mathrm{C}$ for $10 \mathrm{~s}$. In the work of Dorsa et al. (1996) work reductions of up to $1.7 \log _{10} \mathrm{CFU} \mathrm{\textrm {cm } ^ { - 2 }}$ were achieved using steam for $30 \mathrm{~s}$ and final APCs ranged from 1.2 to 
$0.9 \log 10 \mathrm{CFU} \mathrm{\textrm {cm } ^ { - 2 }}$. The results achieved in these experiments are therefore very similar.

In Conclusion this work demonstrated that decontamination treatments are, and can be, effective in reducing total viable microbial counts on sheep sacrifice carcasses without significantly affecting carcass quality. In all cases there was no significant difference between treated and untreated carcasses in terms of lean appearance, colour appearance, odour, and overall acceptability after $48 \mathrm{~h}$ of chilling and chilled storage.

The position of the sampling site directly affects the measured reduction in APC. In both the immersion treatments, the abdomen had a longer processing time than the neck due to the method of hoisting the carcass from the hindlegs. Further development is required to overcome this problem and optimise the steam distribution and design of a commercial system. In addition, the antibacterial action of chlorine together with hot water has been investigated. Kotula et al. (1974), Anderson et al. (1981) and Gregory and Siragusa, (1995) reported that washing beef forequarters with chlorinated water (200 ppm) could reduce total aerobic counts by up to $5 \log$ units.

\section{ACKNOWLEDGEMENTS}

The author would like to thank the management and staff of The Custodian of the Two Holy Mosques Institute for Hajj Research, Umm Al-Qura University, KSA. I would also like to thank Dr. Zohair Mulla, for his helping with the microbial sampling.

\section{REFERENCES}

Al-sheddy, I.; Daniel, Y.; Fung, C. and Kastner, C. (1995): Microbiology of fresh and restructured lamb meat: A Review. Critical Reviews in Microbiology 21 (1): 31-52.

Anderson, M.; Marshall, R. and Dickson, J. (1981): Estimating depths of bacterial penetration into post-rigor carcass tissue during washing Journal of Food Safety. 12 (3): 191-198.

Bailey, C. (1971): Spray washing of lamb carcasses. In Proceedings of the 17th European Meeting of Meat Research Workers (Paper B16, pp. 175-181). Bristol, UK.

Bailey, C. (1972): Spray washing of lamb carcasses. Institute of Meat Bulletin. 75: 3-12. 
Bailey, C. and Roberts, T.A. (1976): Spray washing - hot, cold or not at all? Meat 24-25.

Corrya, J.; Jamesb, C.; Jamesc, S. and Hinton, M. (1995): Salmonella, Campylobacter and Escherichia coli 0157:H7 decontamination techniques for the future. International Journal of Food Microbiology. 28 (2): 187-196.

Corrya, J.; James, S.; Purnell, G.; Pinto, S.; Chochois, Y.; Howell, M. and James, C. (2007): Surface pasteurization of chicken carcasses using hot water. Journal of Food Engineering. 79: 913-919.

Dorsa, W.; Cutter, C.; Siragusa, G. and Koohmarie, M. (1996): Microbial decontamination of beef and sheep carcasses by steam, hot water spray washes, and a steam-vacuum sanitiser. J. Food Prot. 59: 127-135.

Downey, G.; McCann, M. and Sheridan, J. (2007): NFC No 087 Surface decontamination of meat using thermal processes. (http://www.teagasc.ie/research/reports/foodprocessing/5048/e opr-5048.pdf).

Ellerbroek, L.; Wegener, J. and Arndt, G. (1993): Does spray washing of lamb carcasses alter bacterial surface contamination. J. Food Prot. 56: 432-436.

Gill, C. and Baker, L. (1998): Assessment of the hygienic performance of a sheep carcass dressing process. J. Food Prot. 61: 329-333.

Gill, C. (1979): A review: intrinsic bacteria in meat. Journal of Applied Bacteriology 47: 367-378.

Gill, C. and Jones, T. (2000): Microbiological sampling of carcasses by excision or swabbing. J. Food Prot. 63: 167-173.

Gill, C. (1980): Total and intramuscular bacterial populations of carcasses and cuts. In Proceedings of the 33rd Annual Reciprocal Meat Conference. Vol. 33: 47-53.

Gill, C.; McGinnis, J. and Badoni, M. (1996): Use of total or Escherichia coli counts to assess the hygienic characteristics of a beef carcass dressing process. International Journal of Food Microbiology. 31(1-3): 181-196.

Gregory, R. and Siragusa, A. (1995): The effectiveness of carcass decontamination systems for controlling the presence of pathogens on the surfaces of meat animal carcasses. Journal of Food Safety. 15 (3): 229-238. 
James, C.; Thornton, J.; Ketteringham, L. and James, S. (2000): Effect of steam condensation, hot water or chlorinated hot water immersion on bacterial numbers and quality of lamb carcasses. Journal of Food Engineering. 43 (4): 219-225.

James, S. and Evans, J. (2006): Predicting the reduction in microbes on the surface of foods during surface pasteurization. the 'Bugdeath' project . Journal of Food Engineering. 76 (1): 1-6.

James, C. and James, S.J. (1997): Meat decontamination- the state of the art. MAFF Advanced Fellowship in Food Process Engineering, University of Bristol, EU concerted action programme CT94 1881, ISBN $086292460 \mathrm{X}$.

Karmas, E. (1975): Fresh meat technology, Food Technology Review No. 23. Noyes Data Corporation, New Jersey.

Kelly, C.; Dempster, I. and Mcloughlin, A. (2007): Effect of hot water spray washing on the appearance of lamb carcasses of different weights. International Journal of Food Science and Technology. (20) 6: 753-761.

Kelly, C.; Dempster, J. and McLoughlin, A. (1981): The effect of temperature, pressure and chlorine concentration of spray washing water on numbers of bacteria on lamb carcasses. Journal of Applied Bacteriology. 51: 415-424.

Kelly, C.; Lynch, B. and McLoughlin, A. (2008): The effect of spray washing on the development of bacterial numbers and storage life of lamb carcasses. Journal of Applied Microbiology. 53 (3): 335-341.

Kelly, C.; Lynch, J. and McLoughlin, A. (1982): The effect of spray washing on the development of bacterial numbers and storage life of lamb carcasses. Journal of Applied Bacteriology. 53: 335-341.

Kotula, A.; Lusby, W.; Crouse, J. and de Vries, B. (1974): Beef carcass washing to reduce bacterial contamination. Journal of Animal Science. 39, 4: 674-679.

María-Luisa Sierra, A.; James, J.; Sheridan, B. and Liam McGuire, (1997): Microbial quality of lamb carcasses during processing and the acridine orange direct countn technique (a modified DEFT) for rapid enumeration of total viable counts. International Journal of Food Microbiology. 36(1): 61-67.

Morgan, A.; Goldberg, N.; Radewonuk, E. and Scullen, O. (1996a): Surface pasteurization of raw poultry meat by steam. Lebensmittel-Wissenschaft und-Technologie. 29: 447-451. 
Morgan, A.; Radewonuk, E. and Scullen, O. (1996b): Ultra high temperature ultra short time surface pasteurization of meat. Journal of Food Science. 61 (6): 1216-1218.

Siragusa, G. (1995): Application of chlorine to reduce populations of Escherichia coli on beef. Journal of Food Safety. 15: 67-75.

Smith, M. and Graham, A. (1978): Destruction of Escherichia coli and salmonellae on mutton carcasses by treatment with hot water. Meat Science 2: 119-128. 